\title{
Sustainable Corporate Strategy: The Role of Human Capital in the Time of COVID-19 Crisis
}

\author{
Petra Jílková \\ Department of Economics and Management, University of Chemistry and Technology Prague, \\ Technická 5, 16628 Prague 6, Czech Republic
}

\begin{abstract}
The paper examines the role of human capital in sustainable corporate strategy, education and discusses the ways it supports corporate social responsibility (CSR). In order to identify how employee benefits and how education can support human capital development, quantitative research was realized via an online survey method through a structured questionnaire. Data were collected during two time intervals, before and during COVID-19 Crisis. We find evidence that employees have transformed their perceptions of employee benefits during the Crisis. The survey showed that with the majority of employees working from home due to the current situation, it is necessary to support more flexible working benefits as an integral part of creating a sustainable strategy. Moreover, the investment in employee education as the condition of sustainability is not supported by most of the investigated companies. Finally, the results indicate that the benefit structure is, for employees, an essential part of their job satisfaction and can support employees' loyalty to the firm.
\end{abstract}

Keywords - Covid-19 Crisis; Education; Human Capital; Sustainable Strategy.

DOI: 10.18421/TEM102-26

https://doi.org/10.18421/TEM102-26

Corresponding author: Petra Jílková,

Department of Economics and Management, University of Chemistry and Technology Prague, Technická 5, 16628

Prague 6, Czech Republic.

Email: jilkova.petra@vscht.cz

Received: 20 January 2021.

Revised: 01 April 2021.

Accepted: 09 April 2021.

Published: 27 May 2021.

(cc) BY-NC-ND (C) 2021 Petra Jílková; published by UIKTEN. This work is licensed under the Creative Commons Attribution-NonCommercial-NoDerivs 4.0 License.

The article is published with Open Access at www.temjournal.com

\section{Introduction}

Over the last few decades, a sustainable strategy has progressively gained importance. A growing number of firms spend many of their resources on corporate social responsibility (CSR) concept supporting the vision of sustainability. According to [1], the broadest definition of CSR is the relationship between business and society. Based on [2], corporate social responsibility presents a valuable tool for better management of enterprises, and the factors of sustainability implemented in the strategy can support innovations and retain customers.

At no time in history has there been such a radical change in working habits as in the COVID-19 Crisis. There were at least ten weeks of lockdowns and social distancing in the first wave of the COVID-19 disease, and the second wave is now in progress. As a result of the pandemic, virtual teams have been supported, work from home has increased, and the demand for different employee skill levels have been created. An immediately noticeable change has been creating a digital workplace, as many firms have had to impose a work-from-home policy. Firms have found out that they need to adopt much more projectby-project organizational structures with better coordination of work-life balance principles.

In this paper, it is examined the role of human capital in sustainable strategy. Based on a literature review focusing on corporate social responsibility as the pillar of a sustainable corporate strategy, the leading role of human capital was defined. The main aim was to explore whether there is a connection among human capital, corporate social responsibility, and human resources management theory.

Based on previous research, there are relations between corporate social responsibility and human resource management theory. Sustainable development connected with corporate social responsibility was highlighted by [3], followed by [4]. The approach developed by [5] highlighted that building social capital among primary stakeholders through CSR activities can help companies to survive 
over time. While better human resource management can support corporate social responsibility, human capital management can support firms' sustainable strategy during the Crisis.

The main goal of this paper is to explore the role of human capital in sustainable strategy. Categorically, this study's secondary aim is to investigate how employees have transformed their perceptions of employee benefits during the Covid-19 Crisis. Finally, we investigate the factors that can support employees' loyalty to the firm. For this reason, quantitative research was realized via an online survey method through a structured questionnaire among a group of 121 respondents who took part in a survey created for this purpose. Respondents were selected from two generational cohorts in two waves, before and during COVID-19 Crisis. The employee benefits were grouped into seven main areas according to employee interests, and the goal of the research was to investigate the differences before and after the COVID-19 Crisis. It is evident that there is an enormous change all over the world caused by COVID-19 Crisis, and it has shaped the reality of sustainable corporate strategy supported by the new business principles.

In this paper, we investigate the role of human capital as the pillar of the sustainable strategy. This paper contributes to the existing research in several ways. First, we extend the corporate social responsibility research on the role of human capital in a sustainable strategy. Secondly, previous papers investigated the modern trends of human capital separately. Thirdly, the ongoing COVID-19 pandemic in 2020 has transformed the perception of employee benefits. Lastly, this evidence supports the need to increase employee loyalty through management decision to invest back to the employees.

The remainder is organized as follows: Section 2 offer the literature review and specifies the rationale of the research; Section 3 discusses the identification method, data used in the empirical analysis and development of the hypotheses; Section 4 summarize and discuss key findings, represents the results, followed by Section 5 with the conclusions.

\section{Literature Review}

There are many definitions and aspects of corporate social responsibility (CSR) concepts and its effect on sustainability and sustainable business strategy issues. The modern concept of social responsibility started with the publication of The Social Responsibilities of the Businessman written by [6], where he pointed out that social responsibility is one of the institutional tools. He mentioned the question: "What is the proper mix of voluntary initiative and coercive pressure most likely to align corporate activities with the public interest?" He was the first author whose social responsibility emerged from the managerial level.

[7] defined corporate social responsibility for academics by systematizing the essential issues that might be taught and managers by showing social responsibility as being just one part of overall business strategy. According to this model, it helps managers systematically think through the major social issues being faced. He agreed with [8] five factors of firms' social involvement: i) matching social need to corporate need; ii) interest of top executives; iii) seriousness of social need; and iv) government pressure. Some researchers present the connection between profitability and sustainability of natural and social resources [9]; some extend the impact on economic growth [10]. Based on [11], sustainable development means that human beings can exist and produce on a long-term basis while providing adequate living conditions. Based on [12], sustainable development is the long-term stability of the economy and environment. It is achievable through the decision making process in connection with economic, social and environmental factors. There are several types of capital (natural, social, human-made), and authors connect sustainable development with the definition of sustainable capital.

[13] define the link among long term success, sustainability, and human resource management (HRM). The existence of this connection is essential for businesses, employees and societal well-being. Human resource management might play an essential role in the guiding process; companies' values and behaviour change towards sustainability. The definition of employees' competencies is a political problem within the organization. According to [14], cost-effective human resource management is the key to organizational success. In line with [15], one of the main causes of project failure is the failure of human capital. Based on this research, in the firm's corporate strategy, there are three core elements necessary for organizational function: i) mission and strategy, ii) organizational structure, and iii) the human resource processes in recruitment and selection of people within the organization.

Sustainability can be relating to institutional, organizational and individual practice, and according to [16], there are several models and theories that have been developed to make our societies more sustainable. [17] introduced how the structures supporting the idea of sustainability within organizations can develop a sustainable business. They highlighted that sustainable development at enterprise contained modern environmental policy, sustainable marketing, green network framework, and certified environmental management system. 
Human capital is a determinant of a sustainable business strategy, and it is not listed on a company's balance sheet. Human capital is positively correlated to output in the production process and economic growth [18]. The human capital theory maintains that knowledge provides individuals with increases in their cognitive abilities, leading to more efficient potential activity. Human capital could be classified as the economic value of an employee's intelligence, skill sets, ideas, education and training, and individuals' health. The origin of the definition of human capital goes back to [19] when he defined that the growth of knowledge contributes to economic growth. In Wealth of Nations, they wrote that human skill is one of the components of capital and that human capital can be developed through many activities, such as formal education in the form of teaching or training, work experience, or other life experiences.

Human capital is the result of the formal education process and includes non-formal education and the cumulative effect of job experience and special training provided by employers. There is a relationship between education, profitability, entrepreneur activity, and success [20]. Based on this theory, there is a relation between intellectual capital and company value. Human Capital is influenced by organizational culture, management values, and interpersonal relations within the firm. Human Capital is connected very closely with social capital. [21] studied the role of CEOs' human capital features on organizational behaviour, which could play a critical role in organizational performance. The return rate on education can be assessed from a personal, social or fiscal point of view. The personal rate of return seeks to describe young peoples' demand for education and the conditions under which a given individual's studies, under certain conditions, will pay off. It will include, on the cost side, the student's private education costs and, on the revenue side, their after-tax earnings.

In contrast, the social rate of return influences society as a whole in collective decisions about education financing through taxes and voting contributions. It includes all costs and revenues for education from the state point of view. On the cost side, education costs can be included, on the revenue side, gross earnings and externalities. In 2017, OECD countries spent an average of $4.9 \%$ of their gross domestic product on educational institutions from primary to tertiary levels. The largest share of funding on tertiary educational institutions in OECD countries comes from public sources. In other words, it means that only $16 \%$ of the funding comes from private sources, leaving the remaining $1 \%$ from international sources. On the other hand, private sources play a crucial role in the financing of tertiary education. For share of enterprises providing courses see Table 1 [22].
Table 1. Share of enterprises providing courses

\begin{tabular}{|c|c|c|c|c|}
\hline 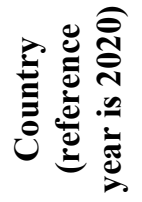 & हే & 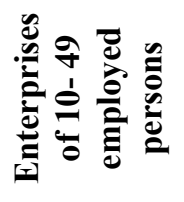 & 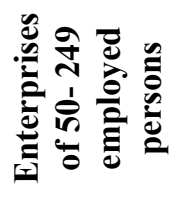 & 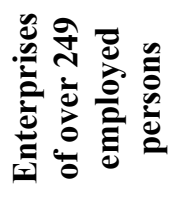 \\
\hline Norway & 99 & 99 & 100 & 100 \\
\hline $\begin{array}{c}\text { Czech } \\
\text { Republic }\end{array}$ & 91 & 89 & 95 & 100 \\
\hline Denmark & 87 & 84 & 95 & 98 \\
\hline $\begin{array}{c}\text { Slovak } \\
\text { Republic }\end{array}$ & 70 & 66 & 83 & 93 \\
\hline Poland & 45 & 39 & 65 & 86 \\
\hline Greece & 22 & 19 & 40 & 68 \\
\hline
\end{tabular}

Source: OECD (2020), Education at Glance.

Sustainable business strategy and development is the source of corporate success and its central pillar of innovation. Sustainable development in connection with corporate social responsibility was highlighted. To increase sustainability it is needed to create a framework to support a firms' development and implement these factors into the sustainable corporate strategy. [23] defined four general sustainability principles, and [24] discussed sustainability as a "responsibility to society" and extended the definition: "there is a need to eliminate negative effects of business". [25] introduced a resource-based view of strategic management. They interpreted sustainable development as development focusing on the use of resources. There are five phases of Corporate Sustainability management: i) basic strategic orientation in the passive or active form (vision statement, mission statement, an organizational culture based on corporate values); ii) strategic management in the form of panning sustainable strategy (corporate objective and classical strategy planning), and iii) operational management in the form of a framework for corporate sustainability with different levels. Based on this concept, a human resource management framework could be created based on strategic marketing process principles. The whole framework is transformed by the modern marketing theory, especially with the Strategic Marketing Process. The approach developed by [26] highlighted that building social capital among primary stakeholders through CSR activities can help companies to survive over time. Together with the previous two theoretical frameworks, the framework gives us the opportunity to highlight Human Capital's role as the pilar of Sustainable Strategy from the theoretical point of view. The model consists of different management levels and is supplemented by marketing instruments to support the Sustainable Strategy based on Human 
Resource Management in the form of Human Capital defined in the research. In connection with the previous research, human capital supports corporate social responsibility in connection with human resources management.

\section{Materials and Methods}

The paper adopted a three-stage model study for the investigation. Firstly, along with the theoretical background based on the literature review, the introduction and main research objectives were created in the preliminary research stage. Secondly, the framework of the research paper in connection with the proposed procedure was set up. Finally, in the conclusion stage, the research examined how human capital in employees' form can help a company and its corresponding sustainable strategy. The methodology used in this paper included analysis, synthesis, and comparison in time.

We examined factors influencing employee attitude among a group of respondents who took part in a survey created for this purpose. In order to identify how employee benefits and education can support human capital development in connection with the Covid-19 Crisis, the research was realized in two waves.

The first wave took place from March 15 to April 15,2019 , and the web-based quantitative survey to 300 respondents with a 0,4 per cent response rate. The relevance of the study was secured by selection sampling. Based on [27], Germany has the largest population of both genders in Europe, and the majority of European countries have a higher population of women. There are $51 \%$ of man in the whole population of the European Union. The data collected from 300 respondents were classified into two main groups according to gender (51\% were men and $49 \%$ women) and age (35\% were aged 18-30 years, 35\% aged 30-50 years, and 30\% aged 50-60 years). In the beginning, we decided how the respondents had to be selected in connection with the employer type. The link to the questionnaire was distributed to employees dividing into ten defined NACE categories (i. A - agriculture, ii. C manufacturing, iii. D - electricity, iv. G - retail, v. I - accommodation, vi. $\mathrm{N}$ - administrative, vii. $\mathrm{O}$ public administration, viii. $\mathrm{P}$ - education, ix. $\mathrm{Q}-$ health, $\mathrm{x}$ S - other services) to the respondents electronically via social networks, especially Facebook and LinkedIn. The popularity of 17 benefits offered from employers to employees in the Czech Republic was investigated.

The second wave took place during the period of the COVID-19 Crisis, from March 15, 2020, to April 15, 2020. Quantitative research was done via an online survey method as well and in this wave were interview 121 successful respondents from the first wave via their email addresses with a 0,67 response rate. This part aimed to investigate the ongoing COVID-19 Crisis influenced the results from the first wave. This part of the research was for respondents more interesting. The online structured questionnaire consisted of 26 questions. When creating questionnaires, closed questions were mainly used. Data is analyzed with the help of descriptive statistics. The introductory part of the survey presented five selective questions which focused on socio-demographic information about the respondents. The first question was focused on gender. A total of 121 people were interviewed, of which $63 \%$ were men and $37 \%$ women. The next question asked the respondent's age, where $49 \%$ were aged 18-30 years, 47\% aged 30-50 years, and 4\% aged 50-60 years. This was followed by a question focused on the highest level of education attained. $67 \%$ of respondents who completed the questionnaire held a university degree (50\% - master's degree, $15 \%$ - bachelor's degree, 2\% - doctoral degree), 25\% with secondary education (21\% with a school-leaving examination, 4\% with an apprenticeship certificate) and $8 \%$ with higher professional education.

For a better understanding of this survey's content, partial goals were set, for which working hypotheses were formulated at the same time. Based on previous studies, the following hypotheses were defined (H1 H4):

- H1: The most popular benefit among employees is Meal Tickets, followed by flexible working benefits in connection with additional financial support.

- H2: There is a need to increase the employees' loyalty through management decision to invest back to the employees and support the human capital.

- H3: The benefit structure is, for employees, an essential part of their job satisfaction and can support employees' loyalty to the firm.

- H4: The ongoing COVID-19 pandemic in 2020 has transformed the perception of employee benefits on behalf of flexible working benefits.

\section{Findings, Results and Discussion}

According to the literature review focusing on the role of corporate social responsibility as the pillar of a sustainable corporate strategy, human capital was defined as the key. COVID-19 pandemic has transformed perceptions of both employer benefits and as well as what sort of employee benefits have been seen as valuable and needed both before and after the COVID-19 Crisis. 


\subsection{Employee perception of benefits and Human Capital support}

Human capital contributes significantly to the overall productivity of the organization. The employer needs to create the process of acquiring, training, and managing employees. The potential for the research in employee benefits is extensive, and our discussion has been limited to the most common or costly types of indirect benefit types. Enterprises spend millions of dollars on benefit plans, and markets try to improve the perceived value of these employee benefits throughout their design, delivery and communication. The main goal is to maximize employee satisfaction in connection with a positive service experience. The structure of the employer benefits before the COVID-19 Crisis is shown in Table 2. What drives employee satisfaction? Because of this fact, it is necessary to identify what employees value the most within offered benefits packages. In the first part of the survey, the popularity of 17 benefits offered from employers to employees in the Czech Republic in 2019 was investigated.

Table 2. Employer benefits before the COVID-19 Crisis

\begin{tabular}{|c|c|}
\hline Benefit Type & $\begin{array}{c}\text { Benefit type (in \%) } \\
\text { (2019) }\end{array}$ \\
\hline Sick Days & 43 \\
\hline $\begin{array}{r}\text { Wage compensation - first three } \\
\text { days of sickness }\end{array}$ & 38 \\
\hline Health care benefits & 41 \\
\hline Corporate kindergarten & 1 \\
\hline Part-time jobs & 45 \\
\hline Flexible working hours & 62 \\
\hline Flexible working benefits & 36 \\
\hline $\begin{array}{l}\text { Possibility to work from home } \\
\text { (Home Office) }\end{array}$ & 37 \\
\hline $\begin{array}{ll}\text { Education } \\
\end{array}$ & 49 \\
\hline $\begin{array}{r}\text { Company car for private } \\
\text { purposes }\end{array}$ & 27 \\
\hline $\begin{array}{l}\text { Professional and career } \\
\text { development benefits }\end{array}$ & 38 \\
\hline Refreshments at work & 35 \\
\hline Exercise activities & 39 \\
\hline $\begin{array}{r}\text { Free time support (holiday } \\
\text { tickets, etc.) }\end{array}$ & 66 \\
\hline $\begin{array}{l}\text { Wellness and preventive } \\
\text { health benefits }\end{array}$ & 47 \\
\hline $\begin{array}{r}\text { Produced products and services } \\
\text { at a discount or for free }\end{array}$ & 24 \\
\hline Providing loans to employees & 89 \\
\hline Life Insurance contribution & 57 \\
\hline Pension savings support & 54 \\
\hline $\begin{array}{r}\text { Free transport to/from } \\
\text { employment }\end{array}$ & 11 \\
\hline Additional financial support & 47 \\
\hline Meal Tickets & 86 \\
\hline
\end{tabular}

Source: author's processing based on authors' research
In spite of the prominence of benefits issues to organizations, there is a surprising general absence of attention given to employee benefits in connection to supporting human capital. However, as far there are few empirical studies that investigate the relationship between financial benefits used by companies and the employees' loyalty [28], [29], [30]. The most popular benefits offered by employers were Meal Tickets $(75 \%$ of employers giving this benefit to their employees), followed by Flexible Working Hours (65\% of employers), Pension Savings Support (57\% of employers), and Part-Time work possibility $(62 \%)$. In line with Ipsos, the research confirmed that the most popular benefit is Meal Tickets (86\%). On the second position are flexible working benefits in the form of flexible working hours (37\%), and parttime work possibility (45\%). Surprisingly, a large percentage of flexible working benefits were not found here (only 36\%). These results correspond with H1 (The most popular benefit among employees is Meal Tickets, followed by flexible working benefits in connection with additional financial support). Pension savings support (54\% of employers), life insurance contribution (45\% of employers), and wage compensation for the first three days of sickness $(38 \%)$ are offered together to more than $47 \%$ of employees. This is a little bit lower than expected. On the other side of the range, only a small number of employers offer company kindergartens ( $1 \%$ of employers).

According to the Education and Training Monitor 2018 [31], $90.6 \%$ of Czech companies provided vocational training to their employees in 2015, and $83.7 \%$ of employees participated (the highest rate in the EU). An education system for supporting and creating a firms' employees' human capital is offered to only $49 \%$ of the investigated employees. Compared to the previous research, the education system is not as important as we had expected, according to $\mathrm{H} 2$. (H2: There is a need to increase the employees' loyalty through management decision to invest back to the employees and support the human capital).

In line with [32], employee loyalty is influenced by a wide range of factors, including employer benefits. Under other conditions, they believe that employees' loyalty, besides economic compensation, is influenced by social factors and motivations. Through the benefits system, the employer creates employee loyalty among its employees [33], which allows an organization to attract and keep employees in competitive markets. The average percentage of employed people who spent time working at home only on a given day increased in the case of managers form 10\% (in 2003 -2007 ) to $13 \%$ (in 2013-2017) [34]. Finally, the final aim was to find out how employee benefits can 
support employee loyalty and how often employers provide education for their employees. The employee benefits offered are crucial for $35 \%$ of employees. Within employees in the age of $18-30$, it is an essential factor for $41 \%$ of them. In both groups, $51 \%$ of respondents mainly used benefits as a comparative tool with competing offers. Only $24 \%$ of the younger age cohort and $17 \%$ of the older generation cohort regularly find out what benefits competing companies offer.

\subsection{Covid-19 Crisis Impact}

While the ongoing COVID-19 Crisis has closed a large number of businesses, it has also, on the other hand, opened a host of new opportunities. Additional benefits and nonmonetary incentive programs have been gaining notice. There is a question, however, about how firms and workers are responding. According to the previous research sections, employee benefits were grouped into seven main areas of employee interest: i) Health care benefits; ii) Flexible working benefits (kindergarten, part-time work, flexible working hours); iii) Possibility to work from home (Home Office); iv) Professional and career development benefits; v) Wellness and preventive health benefits; vi) Additional financial support; and vii) Meal Tickets. Figure 1 shows how the Covid-19 Crisis has changed the perception of the benefits system.

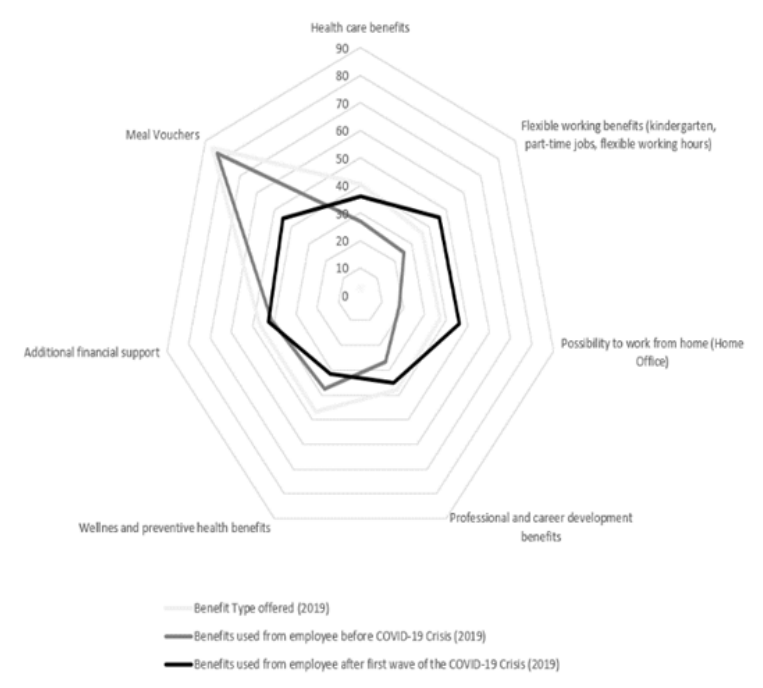

Figure 1. Employer benefits - 7 main areas, author's processing based on research

As the world has become more and more connected than at any other point in history, working from home has become both more comfortable and more common than ever before. This Covid-19 Crisis has had a significant impact on employees as individuals, as a society and as a workforce. In the pandemic, there is an increase in flexible working benefits in connection with the possibility to work from home. On the other hand, there is a decrease in meal ticket benefits. This research found that younger people were more likely to change their working habits due to the Covid-19 Crisis. $46 \%$ of employees switched to working from home and flexible working benefits, and the possibility to stay at home is crucial. Besides, $18 \%$ of these employees had already been working from home before the COVID-19 Crisis began.

\section{Conclusion}

The COVID-19 Crisis has created opportunities and challenges, and there is no doubt that human capital in the form of employees' knowledge is essential for sustainable strategy design. Due to economic slowdown, the quick and flexible sustainable strategy creation could be a source of company's profitability and one of the bases for innovation for the future. Based on a literature review of corporate social responsibility, corporate sustainability, and human capital, a framework for a sustainable strategy where human capital is the central pillar was defined. This framework enables the integration of sustainable relevance from a strategic point of view. The COVID-19 Crisis has shaped recent developments in this area, and many companies face a new reality. The most popular employee benefit was found to be Meal Tickets. This benefit is offered by $86 \%$ of employers compared to the $\mathrm{H} 1$ statement (where it is $11 \%$ more).

Compared with the previous research, employers' education system is not as important as we had expected. As the world becomes connected, flexible working benefits are becoming more valuable, especially connected with the COVID-19 Crisis. 64\% of employees working from home due to the situation with the COVID-19 Crisis. What is the future of flexible working from home?

The COVID-19 Crisis as the global problem of 2020 is a wake-up call for rethinking organizational strategies, and it is the necessary impulse for supporting more flexible working benefits as an integral part of creating sustainable strategy in connection with creating a new set of business principles. From a sustainable strategy perspective, there are several challenges to navigate. Firstly, there are many possibilities for employers on how their working policy could be change. The segment will be essential for this employee to offer them flexible working benefits (kindergarten, part-time work, flexible working hours). Some workers would prefer to continue to work from home. Secondly, more video conferences and meetings will be a new reality. Lastly, there is a segment of employees who will not work from home. In this case, there is a question of how offices change their character. There will be a 
social distancing impact, and new standard layout has to be defined, and new employee benefits will be created. Besides, some people lost their jobs due to COVID-19 Crisis. Although the consequences of the Covid-19 Crisis are mainly negative, in the long term, it may open new business opportunities based on radical changes not only in employee benefits strategy but also in the whole sustainable strategy of the enterprises.

The survey showed that with $64 \%$ of employees working from home due to the current situation, it is necessary to support more flexible working benefits as an integral part of creating sustainable strategy in connection with creating a new set of business principles. There are three main limitations of this research. The first limitation is that the research is not done internationally. The second limitation is the time horizon. Future studies should be done in a longitudinal time horizon to explore the complexities of the COVID-19 impact on human resources and its role in sustainable corporate strategy. The third limitation is that the respondents of the research are employees. For a more in-depth understanding of the COVID-19 crisis impact on corporate social responsibility, future research could be connected with the research among enterprises.

\section{References}

[1]. Fedorova, A., Dvorakova, Z., \& Koropets, O. (2020). Transformation of labour relations in the context of global economic and social risks. International Journal of Monetary Economics and Finance, 13(3), 206-214.

[2]. Belas, J., Çera, G., Dvorský, J., \& Čepel, M. (2020). Corporate social responsibility and sustainability issues of small-andmedium-sized enterprises. Corporate Social Responsibility and Environmental Management, 28(2), 721-730.

[3]. Harkusha, S. A., Hlushachenko, A. I., \& Dovzhyk, O. O. (2018). Organizational and Economic Approaches to Entrepreneurship Development at the Regional Level in Ukraine. Journal of Advanced Research in Law and Economics, 9(6 (36)), 1962-1971.

[4]. Çera, G., Belas, J., Marousek, J., \& Çera, E. (2020). Do Size and Age Of Small and Medium-Sized Enterprises Matter in Corporate Social Responsibility?. Economics \& Sociology, 13(2), 8699.

[5]. Ahn, S. Y., \& Park, D. J. (2018). Corporate social responsibility and corporate longevity: The mediating role of social capital and moral legitimacy in Korea. Journal of Business Ethics, 150(1), 117-134.

[6]. Bowen, H. R. (2013). Social responsibilities of the businessman. University of Iowa Press.

[7]. Carroll, A. B. (1979). A three-dimensional model of corporate social responsibility. Academy of management Review, 4(2), 497-505.
[8]. Holmes, S. L. (1976). Executive perceptions of corporate social responsibility. Business horizons, 19(3), 34-40.

[9]. Banerjee, S. B. (2003). Who sustains whose development? Sustainable development and the reinvention of nature. Organization studies, 24(1), 143-180.

[10]. Harkusha, S. A., Hlushachenko, A. I., \& Dovzhyk, O. O. (2018). Organizational and Economic Approaches to Entrepreneurship Development at the Regional Level in Ukraine. Journal of Advanced Research in Law and Economics, 9(6 (36)), 19621971.

[11]. Borowy, I. (2013). Defining sustainable development for our common future: A history of the World Commission on Environment and Development (Brundtland Commission). Routledge.

[12]. Cerin, P. (2006). Bringing economic opportunity into line with environmental influence: A discussion on the Coase theorem and the Porter and van der Linde hypothesis. Ecological Economics, 56(2), 209-225.

[13]. Paauwe, J. (2009). HRM and performance: Achievements, methodological issues and prospects. Journal of Management studies, 46(1), 129-142.

[14]. Beer, M., Voelpel, S. C., Leibold, M., \& Tekie, E. B. (2005). Strategic management as organizational learning: Developing fit and alignment through a disciplined process. Long Range Planning, 38(5), 445-465.

[15]. Vaníčková, R. (2021). The Influence of the Human Factor on the Success of the Localization Project of the Automated Technological Line for Wood Production. TEM Journal, 10(1), 5-12.

[16]. Baumgartner, R. J., \& Ebner, D. (2010). Corporate sustainability strategies: sustainability profiles and maturity levels. Sustainable Development, 18(2), 7689.

[17]. Silva, M. E., \& Figueiredo, M. D. (2017). Sustainability as practice: Reflections on the creation of an institutional logic. Sustainability, 9(10), 1839.

[18]. Su, Y., \& Liu, Z. (2016). The impact of foreign direct investment and human capital on economic growth: Evidence from Chinese cities. China Economic Review, 37, 97-109.

[19]. Smith, A. (1937). The wealth of nations. modern library. New York, 423.

[20]. Davidsson, P., \& Honig, B. (2003). The role of social and human capital among nascent entrepreneurs. Journal of business venturing, 18(3), 301-331.

[21]. Boone, C., De Brabander, B., \& Van Witteloostuijn, A. (1996). CEO locus of control and small firm performance: An integrative framework and empirical test. Journal of management studies, 33(5), 667-700.

[22]. OECD (2020). Education at Glance 2020: OECD Indicators, Paris: OECD Publishing, 149-151.

[23]. Robèrt, K. H., Schmidt-Bleek, B., De Larderel, J. A., Basile, G., Jansen, J. L., Kuehr, R., ... \& Wackernagel, M. (2002). Strategic sustainable development-selection, design and synergies of applied tools. Journal of Cleaner production, 10(3), 197-214. 
[24]. Carpenter, G., \& White, P. (2004). Sustainable development: finding the real business case. Corporate Environmental Strategy: International Journal for Sustainable Business, 11(2), $2-51$.

[25]. Baumgartner, R. J., \& Ebner, D. (2010). Corporate sustainability strategies: sustainability profiles and maturity levels. Sustainable Development, 18(2), 7689.

[26]. Ahn, S. Y., \& Park, D. J. (2018). Corporate social responsibility and corporate longevity: The mediating role of social capital and moral legitimacy in Korea. Journal of Business Ethics, 150(1), 117-134.

[27]. Dulebohn, J. H., Molloy, J. C., Pichler, S. M., \& Murray, B. (2009). Employee benefits: Literature review and emerging issues. Human Resource Management Review, 19(2), 86-103.

[28]. Condly, S. J., Clark, R. E., and Stolovitch, H. D. (2008). The effects of incentives on workplace performance: A meta-analytic review of research studies. Performance Improvement Quarterly, 16, 4663.
[29]. Garbers, Y., \& Konradt, U. (2014). The effect of financial incentives on performance: A quantitative review of individual and team-based financial incentives. Journal of Occupational and Organizational Psychology, 87(1), 102-137.

[30]. Shaw, J. D., \& Gupta, N. (2015). Let the evidence speak again! Financial incentives are more effective than we thought. Human Resource Management Journal, 25(3), 281-293.

[31]. Publications Office of the EU (2019). Education and Training Monitor 2019, 96. Retrieved from: https://op.europa.eu/en/publication-detail//publication/15d70dc3-e00e-11e9-9c4e-01aa75ed71a1 [accessed: 10 January 2021].

[32]. Ineson, E. M., \& Berechet, G. (2011). Employee loyalty in hotels: Romanian experiences. Journal of human resources in hospitality \& tourism, 10(2), 129149.

[33]. Saragih, R; Prasetio, A. P. 2020. Effective Human Resources Practice and Employee Engagement: The Mediating Roles of Organizational Support. J. Mgt. Mkt. Review, 5(1), 74-83.

[34]. Krantz-Kentkrantz, R. M. (2019). Where did workers perform their jobs in the early 21 st century? Monthly Labor Review, 1-10. 